\title{
QUANTIFICATION OF ALUMINIUM IN SOIL OF THE SOLIMÕES FORMATION, ACRE STATE, BRAZIL ${ }^{(1)}$
}

\author{
Thiago Andrade Bernini ${ }^{(2)}$, Marcos Gervasio Pereira ${ }^{(3)}$, Lúcia Helena Cunha dos Anjos ${ }^{(3)}$, \\ Daniel Vidal Perez ${ }^{(4)}$, Ademir Fontana ${ }^{(4)}$, Sebastião Barreiros Calderano ${ }^{(4)}$ \& Paulo \\ Guilherme Salvador Wadt ${ }^{(5)}$
}

\begin{abstract}
SUMMARY
The variety of soils in the State of Acre is wide and their chemical profiles are still not fully understood. The nature of the material of origin of these soils is indicated by the high aluminium (Al) content, commonly associated with high calcium $(\mathrm{Ca})$ and magnesium $(\mathrm{Mg})$ contents. The study objective was to use different methods to quantify $\mathrm{Al}$ in soils from toposequences formed from material of a sedimentary nature originating from the Solimões Formation, in Acre, Brazil. Trenches were opened at three distinct points in the landscape: shoulder, backslope and footslope positions. Soil samples were collected for physical, chemical, mineralogical analyses. The Al content was quantified using different methods. High Al contents were found in most of these horizons, associated with high $\mathrm{Ca}$ and $\mathrm{Mg}$ levels, representing the predominant cations in the sum of exchangeable bases. The mineralogy indicates that the soils are still in a low weathering phase, with the presence of significant quantities of 2:1 minerals. Similar Al contents were determined by the methods of $\mathrm{NaOH}$ titration, xylenol orange spectrometry and inductively coupled plasma optical emission spectrometry. However, no consistent data were obtained by the pyrocatechol violet method. Extraction with KCl overestimated the exchangeable $\mathrm{Al}$ content due to its ability to extract the non-exchangeable $\mathrm{Al}$
\end{abstract}

(1) Part of the Master Dissertation of the first author, presented in the Agronomy Graduate Course - Soil Science (CPGA-CS Pós-Graduação em Agronomia - Ciência do Solo) at the Rural Federal University of Rio de Janeiro (UFRRJ). Project conducted with support from the National Council for Scientific and Technological Development (CNPq). Received for publication on April 30, 2013 and approved on August 30, 2013.

(2) Agronomist, MSc from CPGA-CS, UFRRJ. BR 465 km 7. CEP 23890-000 Seropédica (RJ), Brazil. CNPq fellowship. E-mail: thiabernini@gmail.com.br

(3) Associate Professor IV, Soils Department, UFRRJ. CNPq fellow and State Scientist of FAPERJ. E-mail: gervasio@ufrrj.br, lanjos@ufrrj.br

(4) Researcher, Embrapa Solos. Rua Jardim Botânico, 1024, Bairro Jardim Botânico. CEP 22460-000 Rio de Janeiro (RJ). E-mail: daniel.perez@embrapa.br, ademir.fontana@embrapa.br, sebastiao.calderano@embrapa.br

(5) Researcher, Embrapa Acre. BR 364, km 14, sentido Porto Velho - RO. CEP 69908-970 Rio Branco (AC). E-mail: paulo.wadt@embrapa.br 
present in the smectite interlayers. It was observed that high $\mathrm{Al}$ contents are related to the instability of the hydroxyl-Al smectite interlayers.

Index terms: exchangeable aluminium, sedimentary material, smectite, western Amazonia.

\title{
RESUMO: QUANTIFICAÇÃO DO ALUMÍNIO EM SOLOS DA FORMAÇÃO SOLIMÕES, ESTADO DO ACRE, BRASIL
}

\begin{abstract}
Há grande variedade de solos no Acre cujos perfis químicos não são ainda totalmente compreendidos. A natureza do material de origem desses solos pode ser observada a partir do teor de alumínio elevado (Al), normalmente associada com níveis elevados de cálcio (Ca) $e$ magnésio (Mg). O objetivo deste estudo foi utilizar diferentes métodos para quantificar o alumínio em solos de topossequências formadas, a partir de um material de natureza sedimentar proveniente da Formação Solimões, Estado do Acre. Foram abertas trincheiras em três pontos distintos: terço superior (P1), terço médio (P2) e terço inferior (P3) da elevação. As amostras de solo foram coletadas para a realização de análises física, química e mineralógica $e$ caracterização do teor de Al. A mineralogia da fração argila foi identificada e o teor de aluminio, quantificado, utilizando diferentes métodos. Na maioria dos horizontes, foram encontrados altos teores de Al, associados a elevados teores de Ca e $\mathrm{Mg}$, os cátions predominantes na soma de bases trocáveis. A mineralogia indica que os solos estão ainda numa fase de baixo intemperismo, com a presença de quantidades significativas de minerais 2:1. O teor de Al determinado pelos métodos de titulação com $\mathrm{NaOH}$, alaranjado de xilenol e espectrometria de plasma, indutivamente acoplado à espectrometria de emissão óptica, foram semelhantes. No entanto, o método de violeta de pirocatecol não apresentou dados consistentes. A extração com $\mathrm{KCl}$ superestimou os teores de Al trocável, em razão da sua capacidade de extrair o Al presente em formas não trocáveis nas intercamadas das esmectitas. Observou-se que o teor de Al elevado está relacionado com a instabilidade das intercamadas das esmectitas hidroxil-Al.
\end{abstract}

Termos de indexação: alumínio trocável, material sedimentar, esmectita, Amazônia ocidental.

\section{INTRODUCTION}

The wide variety of soils in the State of Acre is the result of geological processes related to tectonic reactivations, historic climatic changes induced by variations of the relative sea level and climate (Rossetti $\&$ Toledo, 2007), as for example in the arid period in the last ice age (Mayle \& Power, 2008). The soils also, received contributions from deposits of materials with different particle size, often associated with the orogeny of the Andean range (Cavalcante, 2006b). The Solimões Formation is noteworthy amongst the various geological formations in the Acre Basin, which covers more than $80 \%$ of the state area of Acre, Brazil. The soils of this region are closely related to the material of origin, with particular physical, chemical and mineralogical characteristics (Möller \& Kitagama, 1982; Möller et al., 1982).

The Andean sediments are suggested as the main factors explaining the presence of minimally weathered clays in these soils (Lima et al., 2006). Smectite, interlayered vermiculites and illites, associated with kaolinites, are common in these soils (Volkoff et al., 1989; Marques et al., 2002), although the contents of aluminium oxides (gibbsites) are either zero or low (Silva, 1999). Due to the presence of this clay type, the soils typically have a cation exchange capacity (CEC) of over $27 \mathrm{cmol}_{\mathrm{c}} \mathrm{kg}^{-1}$ clay. In general, the soil calcium $(\mathrm{Ca})$ and magnesium $(\mathrm{Mg})$ contents are high, often associated with high aluminium (Al) levels, so that some may have aluminic or alitic characteristics (Embrapa, 2006).

Another aspect of the high $\mathrm{Al}$ contents is that the element can be in non-exchangeable form. It is also questionable whether the titration method is effective to determine exchangeable $\mathrm{Al}$. In a study of samples of different soils from the Northeast and region of Jaguariúna, in São Paulo State, Boeira et al. (2004) observed that the titration method determined significantly higher $\mathrm{Al}$ contents than the xylenol orange spectrophotometry method. The authors attribute these results to titrating with $\mathrm{NaOH}$, which neutralises other acid forms in addition to those resulting from $\mathrm{Al}$ hydrolysis.

Unbuffered neutral salt solutions have been used to extract Al from soil samples since the 1960s (Brauner, 1966). A solution of $1 \mathrm{~mol} \mathrm{~L}^{-1} \mathrm{KCl}$ has been considered the most suitable extractant for quantifying $\mathrm{Al}$ (Raij et al., 1987; Hiradate et al., 1998). This solution is also less susceptible to ion interference (Coscione et al., 1998).

Aluminium determined by these extractants may overestimate the non-exchangeable species (hydroxyl$\mathrm{Al}$ ) in dissolution. The dissolution of hydroxyl-Al is affected by $\mathrm{pH}$, concentration, the chemical 
characteristics of the extractant and the extraction time (Kissel et al., 1971; Oates \& Kamprath, 1983). While extraction with $\mathrm{KCl}$ removes both exchangeable and non-exchangeable $\mathrm{Al}$ (Oates \& Kamprath, 1983), the contribution of non-exchangeable $\mathrm{Al}$ can be considered insignificant in acid soils in Brazil (Pavan, 1983). However, the exchangeable $\mathrm{Al}$ method did not appear promising to estimate the lime requirement of 2:1 clay soils in a region of North Carolina, USA (Kamprath, 1970). Gama \& Kielh (1999) found low Al phytotoxicity, indicating that the exchangeable $\mathrm{Al}$ would not be suitable to test the acidity in these soils.

Based on the above considerations, the present study had the objective of using different methods to quantify $\mathrm{Al}$ in soils from three toposequences formed from material of a sedimentary nature originating from the Solimões Formation, Acre State, Brazil.

\section{MATERIAL AND METHDS}

\section{Physical environment}

The areas studied are located in the counties of Sena Madureira (S9 03.237 W68 57.796), Manoel Urbano (S8 43.740 W69 31.242) and Feijó (S8 31.985 W69 59.184), in the State of Acre, Brazil (Figure 1).

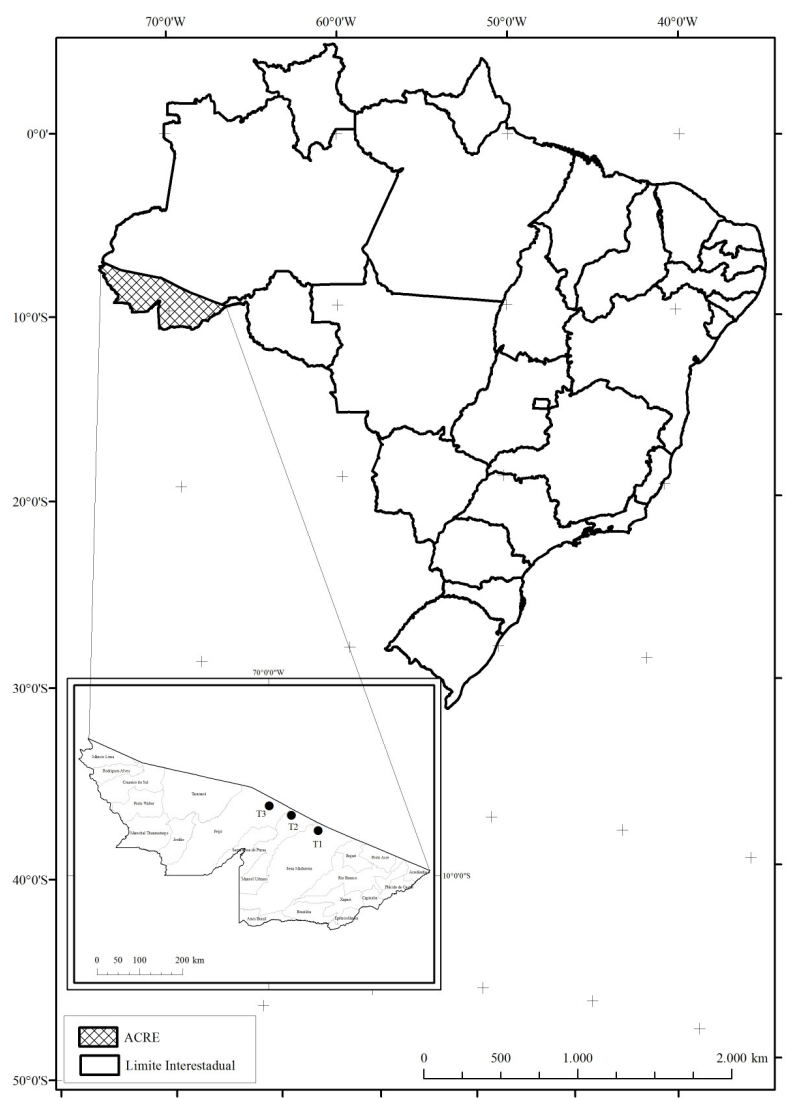

Figure 1. Localization of the toposequences in each county.
The regional climate is characterised by high temperatures, with a mean temperature of $24.5^{\circ} \mathrm{C}$, and high rainfall, with an annual mean of over $1,600 \mathrm{~mm}$. It is defined by the Köppen system as Aw, tropical climate with dry winter season, and Am, tropical wet (Brasil, 1976). The geology is typical of the Solimões Formation, with pelitic and psammitic sediments from Cenozoic deposits. The predominant materials of the formation are carbonate and gypsiferous concretions, occasionally with carbonized material (peat and lignite), sparse pyrite concentrations, and a large quantity of vertebrate and invertebrate fossils. Subordinately, there are siltites, siltic-argillaceous limestones, ferruginous sandstones, and plomitic conglomerates (Cavalcante, 2006a).

Trenches were opened at three points in the toposequence (T1, T2 and T3) of each location: shoulder position (P1), backslope (P2) and footslope (P3). The toposequences are located in areas of undulated tops in the local relief, with convex and concave sides. The slope length varies from 150 to $250 \mathrm{~m}$. The profiles were characterized according to the Manual for Describing and Collecting Soil in the Field (Santos et al., 2005). Soil samples from each horizon were collected for physical and chemical characterisation. Subsequently the soils were classified according to the Brazilian Soil Classification System (Embrapa, 2006) and Soil Taxonomy (Soil Survey Staff, 1999), as given in table 1. After the soil profiles had been characterised and classified, representative subsurface horizons were selected for study.

\section{Laboratory analysis}

The material was air-dried after collection and sieved (mesh $2.00 \mathrm{~mm}$ ), thus producing air-dried fine soil (FADS). The physical analysis consisted of: particle size, using the dispersion method and $0.1 \mathrm{~mol} \mathrm{~L}^{-1}$ sodium hydroxide. The chemical characterization involved the quantification of the $\mathrm{Ca}^{2+}, \mathrm{Mg}^{2+}$ and $\mathrm{Al}^{3+}$, extracted with $1 \mathrm{~mol} \mathrm{~L}^{-1} \mathrm{KCl}$. Extraction of $\mathrm{H}+\mathrm{Al}$ was achieved with a $0.5 \mathrm{~mol} \mathrm{~L}^{-1}$ solution of calcium acetate at $\mathrm{pH}$ 7.0. The $\mathrm{P}, \mathrm{Na}^{+}$and $\mathrm{K}^{+}$contents were extracted with a solution of $0.0125 \mathrm{~mol} \mathrm{~L}^{-1} \mathrm{H}_{2} \mathrm{SO}_{4}+0.05 \mathrm{~mol} \mathrm{~L}^{-1}$ $\mathrm{HCl}$. The $\mathrm{Ca}^{2+}$ and $\mathrm{Mg}^{2+}$ contents were determined by titration with $0.0125 \mathrm{~mol} \mathrm{~L}^{-1}$ EDTA solution; $\mathrm{Na}^{+}$and $\mathrm{K}$, by flame photometry; $\mathrm{P}$ by colourimetry; and $\mathrm{Al}^{3+}$ and $\mathrm{H}+\mathrm{Al}$, by titration with $0.025 \mathrm{~mol} \mathrm{~L}^{-1} \mathrm{NaOH}$. The $\mathrm{pH}$ in $\mathrm{H}_{2} \mathrm{O}$ and in $\mathrm{KCl}$ (1:2.5 weight) was determined by means of a potentiometer. The organic carbon (C.org) content was determined by wet oxidation. From these data we calculated: aluminium saturation (m); $\mathrm{S}$ value (sum of exchangeable bases); $\mathrm{T}$ value (soil CEC), clay CEC and V\% value. The above procedures were carried out as described by Embrapa (1997).

The specific surface of the ground and sieved (60mesh) FADS was determined. Adsorption was measured using ethylene glycol monomethyl ether (EGME), as proposed by Carter et al. (1965), Heilman et al. (1965) and modified by Cihacek \& Bremner 
Table 1. Classification of the soil profiles studied using the Brazilian Soil Classification System (SiBCS) and Soil Taxonomy

\begin{tabular}{clc}
\hline Toposequence/profile & \multicolumn{1}{c}{ SiBCS $^{(1)}$} & Soil Taxonomy $^{(2)}$ \\
\hline T1P1 & Typic haplic orthic Vertisol Chromic Hapluderts \\
T1P2 & Typic haplic Ta eutrophic Cambisol & Typic Dystrudepts \\
T1P3 & Typic haplic Ta eutrophic Cambisol & Typic Dystrudepts \\
T2P1 & Plinthic Red-Yellow alitic Argisol & Typic Plinthudults \\
T2P2 & Typic haplic Ta eutrophic Cambisol & Typic Dystrudepts \\
T2P3 & Typic haplic Ta eutrophic Gleysol & Typic Udorthents \\
T3P1 & Plinthic Red Alitic Argisol & Typic Plinthudults \\
T3P2 & Typic Grey dystrophic Argisol & Typic Plinthudults \\
T3P3 & Typic haplic Ta eutrophic Cambisol & Vertic Dystrudepts \\
\hline
\end{tabular}

(1) Embrapa (2006); ${ }^{(2)}$ Soil Survey Staff (1999).

(1979). A $1.0 \mathrm{~g}$ sample mass was weighed and then $3.0 \mathrm{~mL}$ EGME was added. The soil material was subjected to vacuum in a desiccator with $\mathrm{CaCl}_{2}$, and weighed at pre-established intervals, until constant weight. Total specific surface (S.s.) was calculated using the equation: S.s. $=$ gEGME $\mathrm{g}^{-1}$ (sample) $\mathrm{x}$ $2.86 \times 10^{-4} \mathrm{~g} \mathrm{~m}^{-2}$.

Sulphuric attack was applied to the clay fraction to quantify the $\mathrm{Fe}, \mathrm{Al}$ and $\mathrm{Ti}$ contents, and silica in the residue was subsequently analysed. The method consisted of boiling the clay in a 1:1 solution of $\mathrm{H}_{2} \mathrm{SO}_{4}$ for 30 min under reflux, cooling and filtering. The $\mathrm{Fe}, \mathrm{Al}$ and Ti contents in the filtrate were determined, and $\mathrm{Si}$ in the residue (Embrapa, 1997). The $\mathrm{SiO}_{2}$, $\mathrm{Al}_{2} \mathrm{O}_{3}, \mathrm{Fe}_{2} \mathrm{O}_{3}$ and $\mathrm{TiO}_{2}$ contents were quantified and expressed as percentages and used to calculate the molecular ratios ki $\left(\mathrm{SiO}_{2} / \mathrm{Al}_{2} \mathrm{O}_{3}\right)$ and $\mathrm{kr}\left(\mathrm{SiO}_{2} / \mathrm{R}_{2} \mathrm{O}_{3}\right)$.

The minerals in the clay fraction were identified by X-ray diffraction (XRD), obtained by sedimentation after dispersion with $1 \mathrm{~mol} \mathrm{~L}^{-1} \mathrm{NaOH}$. The fresh samples were analysed with the following treatments: deferrification by CBD (citrate-bicarbonate-sodium dithionite), in accordance with Mehra \& Jackson (1960); K saturation and, after mounting on a slide, heating for $2 \mathrm{~h}$ at 110,350 and $550{ }^{\circ} \mathrm{C}$; saturation with $\mathrm{Mg}$ and solvation with ethylene glycol, as described by Embrapa (1997) and Calderano et al. (2009). Smearing was used to prepare oriented slides.

The clay fraction was mounted on oriented slides with a suspension of total clay $(<2.0 \mu \mathrm{m})$. Analyses were conducted with a Rigaku diffractometer, model Miniflex II, using $\mathrm{K} \alpha$ radiation with $\lambda 0.15405 \mathrm{~nm}$, produced by a copper tube, $30 \mathrm{kv}$ and $15 \mathrm{~mA}$, with a sweep amplitude from 2 to $45^{\circ} 2 \theta$.

The diffractograms were produced using the Microcal Origin 6.0 software and presented in the following order: untreated sample (Am. total); ironfree sample saturated with magnesium $(\mathrm{Mg})$ and subsequently solvated with ethylene glycol (MgEG); iron-free sample saturated with $K$, with sweeps at room temperature (K25) and, after heating, at the indicated temperatures (K350 and K550). The diffractograms were interpreted based on the tables and criteria of Thorez (1976), Brindley \& Brown (1984) and Moore \& Reynolds Jr. (1997). The orthography of the mineral names is in conformity with Branco (1987).

To quantify exchangeable aluminium, extracts were produced using $1 \mathrm{~mol} \mathrm{~L}^{-1} \mathrm{KCl}$ at a ratio of 1:10. The exchangeable Al content in the extracts was determined using: titration (Al_Na), with $0.025 \mathrm{~mol} \mathrm{~L}^{-1}$ $\mathrm{NaOH}$ solution as titrate and bromothymol blue as the turning point indicator (Embrapa, 1997); xylenol orange colourimetry (Al_AX) with UV-Vis spectrophotometer colour reading at $555 \mathrm{~nm}$, as described by Coscione et al. (2000); pyrocatechol violet colourimetry (PVC), allowing discrimination of monomeric (Al_VPM) and total (Al_VPT) aluminium forms, with spectrophotometry absorbance readings at $577 \mathrm{~nm}$, as described by Dougan \& Wilson (1974) and; inductively coupled plasma optical emission spectrometry - ICP-OES (Al_Pl). The ICP-OES method was also used to determine the water-soluble aluminium $\left(\mathrm{Al}_{\mathrm{sol}}\right)$ content, following Embrapa (1997).

The equipment for ICP-OES was a Perkin-Elmer model OPTIMA 3000 of Embrapa-Solos, with the operating conditions: radiofrequency power $1500 \mathrm{~W}$, plasma argon flow $15 \mathrm{~L} \mathrm{~min}^{-1}$, auxiliary argon flow $0.5 \mathrm{~L} \mathrm{~min}^{-1}$, nebulizer argon flow $0.7 \mathrm{~L} \mathrm{~min}^{-1}$, and sample aspiration rate of $2.0 \mathrm{~mL} \mathrm{~min}{ }^{-1}$.

Conclusions on the data were drawn on the basis of the Pearson correlation and the F test.

\section{RESULTS AND DISCUSSION}

\section{Chemical and physical characteristics}

The chemical analysis results are presented in table 2. It was observed that the organic carbon (C.org) contents in the horizons were low $\left(0.7-4.6 \mathrm{~g} \mathrm{~kg}^{-1}\right)$. These values are probably related to the high 
Table 2. Chemical and physical properties of the soil horizons

\begin{tabular}{|c|c|c|c|c|c|c|c|c|c|c|c|c|c|c|c|c|}
\hline \multirow{2}{*}{ Profile/horizon } & \multicolumn{2}{|c|}{$\mathrm{pH}$} & \multirow{2}{*}{$\mathrm{H}+\mathrm{Al}$} & \multirow{2}{*}{$\mathrm{Al}^{3+}$} & \multirow{2}{*}{$\mathrm{Ca}^{2+}$} & \multirow{2}{*}{$\mathrm{Mg}^{2+}$} & \multirow{2}{*}{$\mathrm{Na}^{+}$} & \multirow{2}{*}{$\mathbf{K}^{+}$} & \multirow{2}{*}{$\operatorname{CTC}^{(1)}$} & \multirow[t]{2}{*}{ V } & \multirow{2}{*}{$\mathbf{m}$} & \multirow{2}{*}{ C.org. } & \multirow{2}{*}{ Sand } & \multirow{2}{*}{ Silt } & \multirow{2}{*}{ Clay } & \multirow{2}{*}{ S.s } \\
\hline & $\mathrm{H}_{2} \mathrm{O}$ & $\mathrm{KCl}$ & & & & & & & & & & & & & & \\
\hline & & & & & $-\mathrm{cmol}_{\mathrm{c}}$ & $\mathrm{kg}^{-1}$ & & & & & 6 & & $-\mathrm{gk}$ & & & $m^{2} g^{-1}$ \\
\hline $\mathrm{T} 1 \mathrm{P} 1 \mathrm{Cv}_{3}$ & 5.3 & 4.0 & 5.4 & 1.5 & 18.0 & 21.5 & 0.5 & 0.2 & 87 & 88 & 4 & 1.8 & 31 & 442 & 527 & 260 \\
\hline $\mathrm{T} 1 \mathrm{P} 12 \mathrm{Cv}$ & 8.0 & 6.9 & 0.2 & 0.0 & 21.4 & 22.6 & 0.8 & 0.1 & 97 & 100 & 0 & 0.7 & 182 & 355 & 463 & 315 \\
\hline $\mathrm{T} 1 \mathrm{P} 22 \mathrm{Bi}_{2}$ & 4.0 & 3.8 & 18.5 & 11.8 & 1.5 & 9.9 & 0.1 & 0.2 & 43 & 39 & 51 & 4.5 & 103 & 197 & 700 & 209 \\
\hline $\mathrm{T} 1 \mathrm{P} 22 \mathrm{C}$ & 4.2 & 3.8 & 18.3 & 13.5 & 1.4 & 16.3 & 0.2 & 0.3 & 81 & 50 & 43 & 1.9 & 120 & 432 & 448 & 213 \\
\hline $\mathrm{T} 1 \mathrm{P} 3 \mathrm{Bi}_{1}$ & 4.3 & 3.8 & 13.4 & 8.4 & 3.5 & 15.0 & 0.0 & 0.2 & 88 & 58 & 31 & 2.7 & 372 & 265 & 363 & 161 \\
\hline T1P3 $2 \mathrm{C}_{2}$ & 5.9 & 3.9 & 3.1 & 0.6 & 13.8 & 7.5 & 0.2 & 0.2 & 168 & 87 & 3 & 0.4 & 240 & 612 & 148 & 125 \\
\hline $\mathrm{T} 2 \mathrm{P} 1 \mathrm{Bt}$ & 3.9 & 3.5 & 21.3 & 14.0 & 1.2 & 7.6 & 0.0 & 0.2 & 44 & 30 & 61 & 4.6 & 61 & 242 & 697 & 219 \\
\hline $\mathrm{T} 2 \mathrm{P} 1 \mathrm{Btf}_{3}$ & 4.3 & 3.6 & 19.0 & 13.6 & 1.4 & 9.7 & 0.1 & 0.2 & 81 & 38 & 55 & 1.5 & 123 & 500 & 377 & 223 \\
\hline $\mathrm{T} 2 \mathrm{P} 2 \mathrm{Bi}_{1}$ & 4.1 & 3.5 & 17.7 & 12.1 & 4.5 & 9.5 & 0.1 & 0.2 & 58 & 45 & 46 & 3.2 & 98 & 349 & 552 & 245 \\
\hline $\mathrm{T} 2 \mathrm{P} 2 \mathrm{C}_{2}$ & 5.5 & 3.7 & 4.0 & 1.3 & 16.7 & 5.4 & 0.4 & 0.1 & 162 & 85 & 6 & 0.7 & 371 & 465 & 164 & 79 \\
\hline $\mathrm{T} 2 \mathrm{P} 32 \mathrm{Bg}$ & 6.0 & 4.0 & 1.8 & 0.6 & 16.0 & 6.3 & 0.5 & 0.5 & 98 & 93 & 3 & 1.2 & 169 & 574 & 257 & 201 \\
\hline $\mathrm{T} 2 \mathrm{P} 32 \mathrm{Cg}_{1}$ & 6.6 & 4.5 & 1.5 & 0.0 & 23.2 & 11.8 & 0.7 & 0.4 & 105 & 96 & 0 & 1.2 & 284 & 357 & 359 & 254 \\
\hline $\mathrm{T} 3 \mathrm{P} 12 \mathrm{Bt}$ & 4.7 & 3.6 & 15.8 & 10.8 & 1.1 & 2.0 & 0.0 & 0.3 & 29 & 18 & 78 & 3.0 & 99 & 230 & 671 & 200 \\
\hline T3P2 Btf & 4.9 & 3.5 & 20.5 & 13.2 & 1.5 & 8.7 & 0.0 & 0.5 & 51 & 34 & 56 & 2.1 & 180 & 210 & 611 & 274 \\
\hline T3P3 Bi & 5.3 & 3.6 & 15.5 & 9.6 & 16.3 & 12.3 & 0.5 & 0.2 & 89 & 65 & 25 & 2.0 & 46 & 448 & 506 & 217 \\
\hline T3P3 $\mathrm{Cv}_{2}$ & 6.1 & 4.8 & 4.0 & 1.0 & 22.5 & 14.9 & 1.1 & 0.6 & 77 & 91 & 3 & 1.0 & 112 & 329 & 560 & 266 \\
\hline
\end{tabular}

(1) Clay CEC; V: saturation indicator; m: aluminium saturation indicator; C.org.: organic carbon; S.s.: specific surface.

mineralisation rates of organic matter in the soil surface, due to the soil-climatic conditions of the region, ie., the high temperature, air humidity and rainfall (Acre, 2000).

Generally, the $\mathrm{pH}$ values in $\mathrm{H}_{2} \mathrm{O}$ were low, but higher than those determined in $\mathrm{KCl}$ solution, indicating the predominance of negative charges. High base saturation was observed, ranging from $18 \%$ in the $2 \mathrm{Bt}$ horizon of the $\mathrm{P} 1$ profile of $\mathrm{T} 3$ to $100 \%$ in the $2 \mathrm{Cv}$ horizon of the $\mathrm{P} 1$ profile of $\mathrm{T} 1$. The values for $\mathrm{Al}$ saturation in these horizons were, respectively, 78 and $0 \%$. The majority of horizons were found to have high $\mathrm{Al}$ content and predominance of $\mathrm{Ca}$ and $\mathrm{Mg}$ in the sum of exchangeable bases, as in the $2 \mathrm{C}$ horizon of the $\mathrm{P} 2$ profile of $\mathrm{T} 1$. In some horizons the $\mathrm{Mg}$ were higher than the Ca contents. This pattern of variation and high $\mathrm{Ca}$ and $\mathrm{Mg}$ contents was also observed by Amaral (2003), in soils of the Solimões Formation in the Iaco-Acre river basin.

In spite of the high active acidity of these soils (low $\mathrm{pH}$ in $\mathrm{H}_{2} \mathrm{O}$ ) and high exchangeable $\mathrm{Al}$ contents, no phytotoxic effect or response to acidity correction has been proven in pot experiments or for varieties of Al-sensitive plants (Gama \& Kiehl, 1999), due to the combination of two factors: the soil Ca content may be mitigating the $\mathrm{Al}$ toxicity. Also, the standard method of $\mathrm{Al}$ extraction $\left(1 \mathrm{~mol} \mathrm{~L}{ }^{-1} \mathrm{KCl}\right)$ may not be suitable for these soils (Gama \& Kiehl, 1999), as it may be extracting part of the $\mathrm{Al}$ that is strongly retained at the adsorbent surface rather than the $\mathrm{Al}$ in equilibrium with the soil solution (Wadt, 2002).

In the profiles studied, the silt and clay were predominant over the sand fraction (Table 2). The specific surface (S.s.) values were relatively high
(79 - $\left.315 \mathrm{~m}^{2} \mathrm{~g}^{-1}\right)$, associated with high cation exchange capacity (CEC) values in the clay fraction (Table 2 ). These results are characteristic of the presence of clay minerals, such as illite and smectite, with high S.s. and high activity. Similar results were found by Gama (1986), with S.s values ranging from 120 to $386 \mathrm{~m}^{2} \mathrm{~g}^{-1}$, demonstrating the close relationship between this value and the soil CEC. According to Volkoff et al. (1989), the material of origin of some soils of the State of Acre is clay composite with high montmorillonite content, with variable illite and vermiculite and low kaolinite levels, resulting in high S.s values.

The values for the molecular ratios $\mathrm{ki}$ and $\mathrm{kr}$ (Table 3) suggest a lower degree of weathering in these horizons, with predominance of $\mathrm{SiO}_{2}$ and low $\mathrm{Fe}_{2} \mathrm{O}_{3}$ values. The low $\mathrm{Fe}_{2} \mathrm{O}_{3}$ content may be due to the high rainfall together with the low soil permeability, creating favourable conditions for iron reduction and removal from the soil (Araújo et al., 2004).

\section{Mineralogy of the clay fraction}

The X-ray diffraction results obtained for the clay fraction are given in table 4 and some example diffractograms in the figure 2 . The presence of the following clay minerals was confirmed: smectite and kaolinite, with the greatest contents, together with quartz and lepidocrocite, in smaller proportions and absent in some samples. The presence of interlayered kaolinite-smectite was observed in the $2 \mathrm{Bt}$ horizon of the $\mathrm{P} 1$ profile of the $\mathrm{T} 3$.

Smectite is very evident, predominant in nearly all analysed horizons, except for the sample from the $2 \mathrm{Bt}$ horizon of the $\mathrm{P} 1$ profile of the T3. The clay mineral is indicated by its main reflection in the $6.5^{\circ}(2 \theta)$ region 
of $\sim 1.40 \mathrm{~nm}$, in the sample saturated with magnesium $(\mathrm{Mg})$, which is shifted (indicating expansion) after treatment with ethylene glycol (MgEG). The intensity and shape of this reflection in the diffractograms for the Mg-saturated sample are noteworthy. The large occurrence of smectite demonstrates that the soils are still in a low weathering phase.

The smectite reflections vary in intensity and width, demonstrating, respectively, variation in the

Table 3. Contents of $\mathrm{Si}, \mathrm{Al}, \mathrm{Fe}$ and Ti, determined by sulphuric attack on clay, and molecular ratios ki and $k r$ for the horizons under study

\begin{tabular}{|c|c|c|c|c|c|c|}
\hline Profile/horizon & $\mathrm{SiO}_{2}$ & $\mathrm{Al}_{2} \mathrm{O}_{3}$ & $\mathrm{Fe}_{2} \mathrm{O}_{3}$ & $\mathrm{TiO}_{2}$ & $\mathbf{k i} \mathbf{i}^{(1)}$ & $\mathbf{k r}^{(2)}$ \\
\hline & & $-\mathrm{g} l$ & -1 & & & \\
\hline $\mathrm{T} 1 \mathrm{P} 1 \mathrm{Cv}_{3}$ & 306 & 204 & 53 & 5.4 & 2.55 & 2.19 \\
\hline $\mathrm{T} 1 \mathrm{P} 12 \mathrm{Cv}$ & 294 & 193 & 56 & 4.9 & 2.59 & 2.18 \\
\hline $\mathrm{T} 1 \mathrm{P} 22 \mathrm{Bi}_{2}$ & 276 & 210 & 50 & 5.3 & 2.23 & 1.94 \\
\hline $\mathrm{T} 1 \mathrm{P} 22 \mathrm{C}$ & 282 & 205 & 57 & 5.3 & 2.34 & 1.99 \\
\hline $\mathrm{T} 1 \mathrm{P} 3 \mathrm{Bi}_{1}$ & 256 & 204 & 55 & 5.3 & 2.13 & 1.82 \\
\hline $\mathrm{T} 1 \mathrm{P} 32 \mathrm{C}_{2}$ & 256 & 197 & 66 & 4.2 & 2.21 & 1.82 \\
\hline $\mathrm{T} 2 \mathrm{P} 1 \mathrm{Bt}$ & 254 & 211 & 66 & 5.3 & 2.05 & 1.71 \\
\hline $\mathrm{T} 2 \mathrm{P} 1 \mathrm{Btf}_{3}$ & 310 & 200 & 63 & 5.4 & 2.64 & 2.19 \\
\hline $\mathrm{T} 2 \mathrm{P} 2 \mathrm{Bi}_{1}$ & 254 & 196 & 63 & 5.0 & 2.2 & 1.83 \\
\hline $\mathrm{T} 2 \mathrm{P} 2 \mathrm{C}_{2}$ & 288 & 185 & 62 & 4.9 & 2.65 & 2.18 \\
\hline $\mathrm{T} 2 \mathrm{P} 32 \mathrm{Bg}$ & 288 & 187 & 69 & 5.0 & 2.62 & 2.12 \\
\hline $\mathrm{T} 2 \mathrm{P} 32 \mathrm{Cg}_{1}$ & 294 & 186 & 65 & 5.2 & 2.69 & 2.20 \\
\hline T3P1 2Bt & 278 & 211 & 70 & 5.8 & 2.24 & 1.85 \\
\hline T3P2 Btf $_{1}$ & 278 & 196 & 67 & 4.9 & 2.41 & 1.98 \\
\hline T3P3 Bi & 250 & 195 & 57 & 4.9 & 2.18 & 1.84 \\
\hline T3P3 $\mathrm{Cv}_{2}$ & 308 & 180 & 67 & 5.2 & 2.91 & 2.35 \\
\hline
\end{tabular}

(1) $\mathrm{ki}=\left(\mathrm{SiO}_{2} / \mathrm{Al}_{2} \mathrm{O}_{3}\right) \times 1.7 ;{ }^{(2)} \mathrm{kr}=\left(\mathrm{SiO}_{2} \times 1.7\right) /\left[\left(\mathrm{Al}_{2} \mathrm{O}_{3}+(0.64 \mathrm{x}\right.\right.$ $\left.\mathrm{Fe}_{2} \mathrm{O}_{3}\right)$. relative proportion and crystallinity degree of the mineral. The presence of larger reflections, that is, a lower crystallinity degree, may be associated with $\mathrm{Al}$ polymers filling the space between the smectite layers, denominated hydroxyl-Al interlayered smectite (HIS), but may also be due to the presence of interlayered kaolinite/smectite.

Mica (an inclusive term for illite) occurs in all horizons, as indicated by its diagnostic reflections at $\sim 8.85^{\circ}, 17.65^{\circ}$ and $26.70^{\circ}(2 \theta)$, which remained stable under the applied treatments. The increase in intensity, observed after heating to $350^{\circ}$ and $550^{\circ} \mathrm{C}$, was due to the collapse of the other 2:1 clay minerals. Its occurrence is quite significant in all horizons, with apparent predominance over kaolinite in nearly all of them.

Evaluating the mineralogy of the western Amazonian region, Marques et al. (2002) observed that clay consisted of smectite, vermiculite and smectite with interlayered hydroxyl resulting from the addition of sediments, solution precipitation and transformation of the primary minerals.

Kaolinite also occurs in all horizons analysed at lower proportions than those mentioned above. Evidence for its presence are well-formed reflections in the regions $12.3^{\circ}, 24.8^{\circ}$ and $37.7^{\circ}(2 \theta)$, which disappear after the sample is heated to $550^{\circ} \mathrm{C}$.

In the $2 \mathrm{Bt}$ horizon of the $\mathrm{P} 1$ profile of the $\mathrm{T} 3$, the presence of kaolinite-smectite was confirmed. Evidence for their presence is given by a band alongside the kaolinite reflections in the sample with $\mathrm{Mg}$ after treatment with ethylene glycol $(\mathrm{MgEg})$, best seen in the reflection at $12.3^{\circ}(2 \theta)$. This reflection should not be confused with the second smectite reflection that also occurs in this region.

The presence of lepidocrocite was also observed in some samples, whose reflection is only perceptible in untreated samples, disappearing after disferrification

Table 4. Estimates of the relative proportions of the mineral constituents of the clay fraction of the analysed horizons

\begin{tabular}{|c|c|c|}
\hline Toposequence/profile & Horizon & Mineralogy \\
\hline $\mathrm{T} 1 \mathrm{P} 1$ & $\mathrm{Cv}_{3}$ & Smectite $>$ mica $>$ kaolinite, lepidocrocite, quartz \\
\hline $\mathrm{T} 1 \mathrm{P} 2$ & $2 \mathrm{Bi}_{2}$ & Smectite $>$ kaolinite $>$ mica, lepidocrocite, quartz \\
\hline $\mathrm{T} 1 \mathrm{P} 2$ & $2 \mathrm{C}$ & Smectite $>$ mica $>$ kaolinite, lepidocrocite, quartz \\
\hline T1P3 & $\mathrm{Bi}_{1}$ & Smectite $>$ mica $>$ kaolinite, lepidocrocite, quartz \\
\hline $\mathrm{T} 2 \mathrm{P} 1$ & $\mathrm{Bt}$ & Smectite $>$ mica $>$ kaolinite, lepidocrocite \\
\hline $\mathrm{T} 2 \mathrm{P} 1$ & $\mathrm{Btf}_{3}$ & Smectite $>$ mica $>$ kaolinite, quartz \\
\hline $\mathrm{T} 2 \mathrm{P} 2$ & $\mathrm{Bi}_{1}$ & Smectite $>$ mica $>$ kaolinite, quartz \\
\hline $\mathrm{T} 2 \mathrm{P} 2$ & $\mathrm{C}_{2}$ & Smectite $>$ mica $>$ kaolinite, quartz \\
\hline $\mathrm{T} 2 \mathrm{P} 3$ & $2 \mathrm{Bg}$ & Smectite $>$ mica $>$ kaolinite, quartz \\
\hline $\mathrm{T} 2 \mathrm{P} 3$ & $2 \mathrm{Cg}_{1}$ & Smectite $>$ mica $>$ kaolinite, quartz \\
\hline $\mathrm{T} 3 \mathrm{P} 1$ & $2 \mathrm{Bt}$ & Smectite $>$ mica $>$ kaolinite $>$ interlayered kaolinite-smectite \\
\hline T3P2 & $\mathrm{Btf}_{1}$ & Smectite $>$ mica $>$ kaolinite, lepidocrocite, quartz \\
\hline T3P3 & $\mathrm{Bi}$ & Smectite $>$ kaolinite $>$ mica, lepidocrocite, quartz \\
\hline T3P3 & $\mathrm{Cv}_{2}$ & Smectite $>$ mica $>$ kaolinite, quartz \\
\hline
\end{tabular}


(a) $\mathrm{T} 1 \mathrm{P} 1 \mathrm{Cv}_{3}$

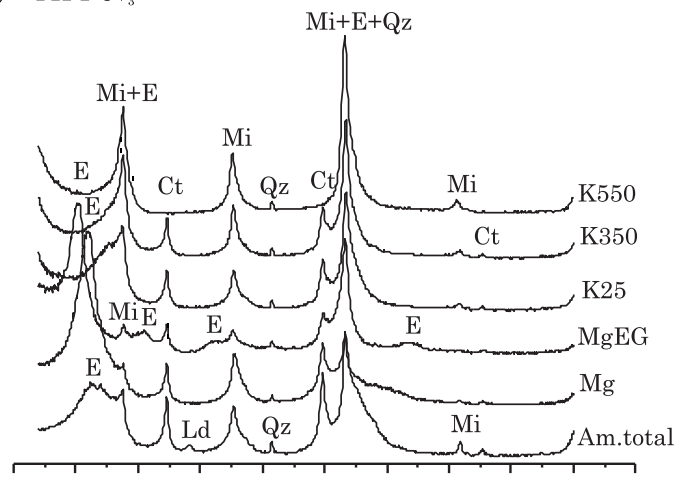

(b) $\mathrm{T} 2 \mathrm{P} 1 \mathrm{Bt}$

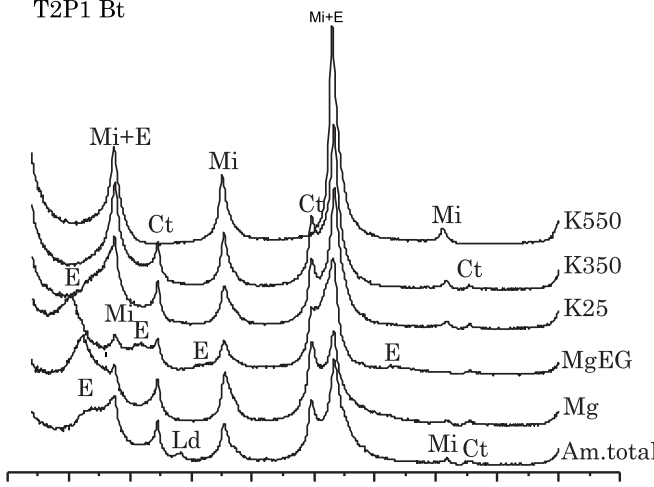

(c) $\mathrm{T} 3 \mathrm{P} 12 \mathrm{Bt}$

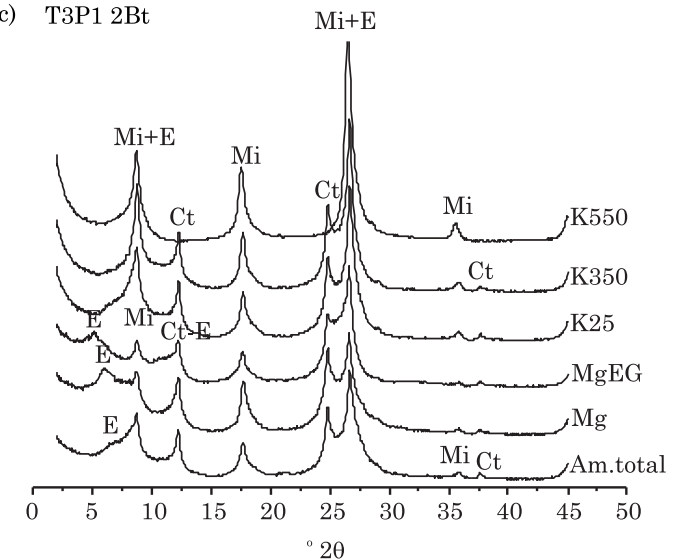

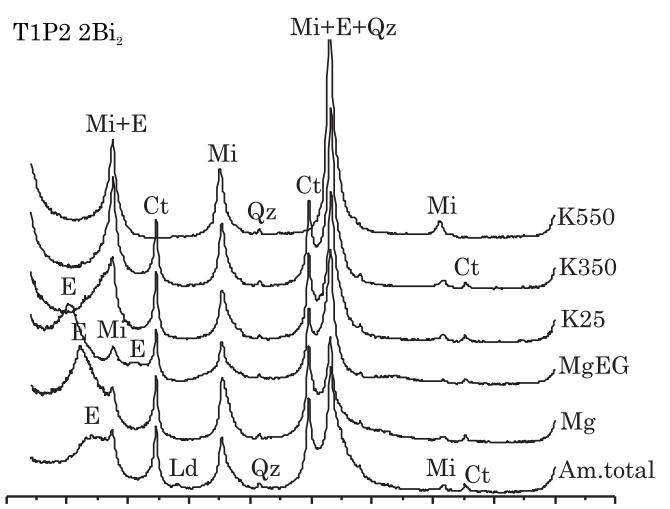

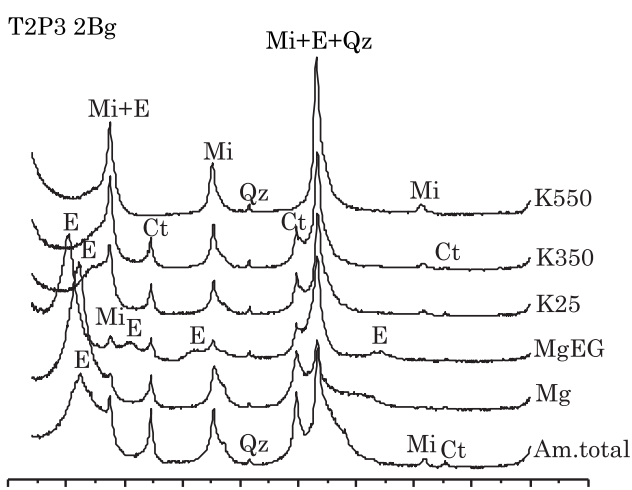

T3P2 2Btf

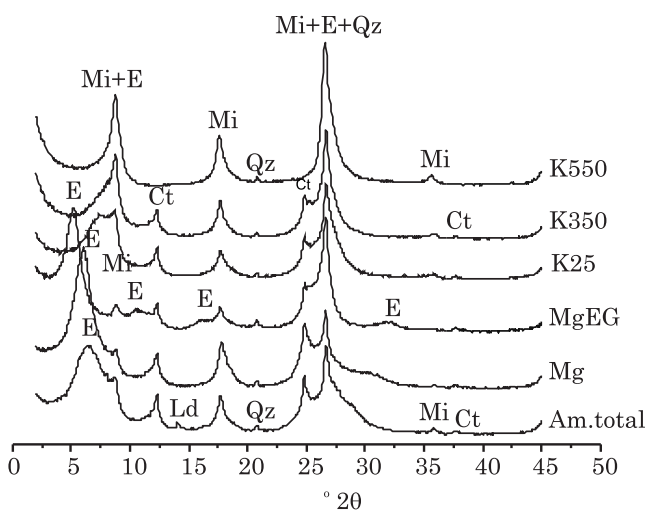

Figure 2. X-ray diffractograms of the clay fraction of the horizons of the T1 (a), T2 (b) and T3 (c) toposequences. E: smectite, Mi: mica, Ct: kaolinite, Ct-E: interlayered kaolinite-smectite, Ld: lepidocrocite, Qz: quartz.

(with dithionite citrate bicarbonate). Quartz is also present, and both in reduced proportions.

There was a tendency for more intense smectite reflections in the spectra of the deepest horizons in all profiles, suggesting the presence of a greater quantity of large and well-crystallised particles. The crystallinity degree of smectite was lower in the shallower horizons. These results demonstrate that the deeper smectites are more protected from weathering processes. According to Lima et al. (2006), the occurrence of smectite may be attributed to the high base ( $\mathrm{Ca}$ and $\mathrm{Mg}$ ) content and of sufficient silica for this mineral to be synthesised and stabilised.
The weathering processes are more intense in better drained environments, favouring $\mathrm{Al}$ release, and together with the great frequency of wetting and drying cycles, promote the formation of HIS, expressed by the wider reflections (Figure 3 ).

Moreover, the high $\mathrm{Al}$ content in these soils may be due to the presence of $2: 1$ clay minerals with interlayered hydroxyl. The filling of the smectite interlayer spaces with $\mathrm{Al}-\mathrm{OH}$ modifies the properties of these minerals, such as: reducing the permanent charge and increasing the variable charge, reducing the internal surface areas (Barnhisel \& Bertsch, 1989) and the capacity for expansion and contraction, as 


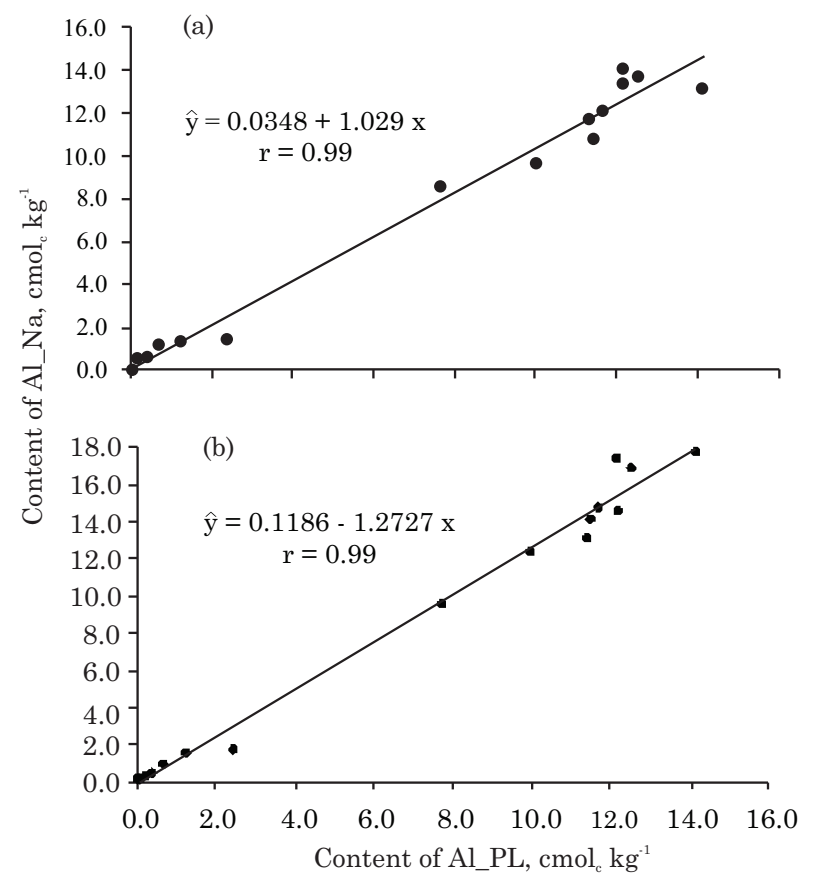

Figure 3. Correlation between aluminium contents determined by ICP-OES (Al_PL) and by titration with $\mathrm{NaOH}$ (Al_Na) (a) and by spectrometry with xylenol orange (Al_Na) (b).

well as, under certain environmental conditions, being the cause of very high Al levels (Kämpf \& Curi, 2003).

These results show that a reducing environment favours the greatest concentration of smectite, as in the $2 \mathrm{Bg}$ and $2 \mathrm{Cg}_{1}$ horizons of the $\mathrm{P} 3$ profile of $\mathrm{T} 2$. On the other hand, environments with better drainage favour HIS, illite and interlayered illite/smectite. In a study of two Cambisols of clay origin from the Guabirotuba Formation in the Curitiba Sedimentary Basin (Paraná State), Melo et al. (2009) identified smectite with interlayered hydroxyl-Al in the horizons closest to the surface ( $\mathrm{A}$ and $\mathrm{Bi}$ ) and smectite in the samples from the $\mathrm{C}$ horizon. The same authors emphasized that even with the limited occurrence of 2:1 minerals in the A horizon, HIS was maintained, which may be due to the presence of hydroxyl-Al in the smectite interlayers, stabilising the $2: 1$ minerals, which are thermodynamically unstable under conditions of greater weathering and silica removal.

In a study of the soils of Rio Branco and Manuel Urbano in Acre, Volkoff et al. (1989) observed that smectites are predominant in younger and deeper horizons, as is characteristic of Inceptsol, and illite predominates in the more developed horizons, as in Argisol, probably due to smectites being degraded.

According to Kämpf \& Curi (2003), smectites are generally saturated with $\mathrm{Ca}$ and $\mathrm{Mg}$. However, $\mathrm{Al}$ is released from the structure upon acidification of the medium, forming $\mathrm{Al}-\mathrm{OH}$ polymers that precipitate in the interlayers, producing smectites with hydroxyl$\mathrm{Al}$ interlayers.

\section{Aluminium contents determined by different methods}

Table 5 shows the $\mathrm{Al}$ content in the horizons studied, extracted with $\mathrm{KCl}$ and water, determined by different methods. It can be observed that the water-soluble $\mathrm{Al}$ contents are very low, demonstrating that practically all $\mathrm{Al}$ determinations by the different methods used in this study was based on $\mathrm{KCl}$ extraction. In general, the $\mathrm{Al}$ contents quantified by xylenol orange spectroscopy (Al_AX) were higher in comparison to values from the other methods (0.2 $17.8 \mathrm{cmol}_{\mathrm{c}} \mathrm{kg}^{-1}$, on average $\left.8.5 \mathrm{cmol}_{\mathrm{c}} \mathrm{kg}^{-1}\right)$.

Aluminium determination by pyrocatechol violet spectrometry was found to be ineffective with little variation or consistency between the values for monomeric $\mathrm{Al}$ (Al_VPM) and total $\mathrm{Al}$ (Al_VPT). In Bi of the P3 profile of T3 (Table 5), the values for monomeric $\mathrm{Al}$ were higher than those for total $\mathrm{Al}$. This result may be due to the method being incapable of determining high $\mathrm{Al}$ concentrations since a significant dilution of the extract is required, which can lead to errors. In a study of Histosols from various regions of Brazil with Al-rich soils, Ebeling (2006) observed that the Al contents quantified by pyrocatechol violet were not consistent with the results of the other methods: titration with $\mathrm{NaOH}$, xylenol orange and ICP-OES.

Lower $\mathrm{Al}$ values were recorded in the $2 \mathrm{Cv}$ horizon of the $\mathrm{P} 1$ profile of $\mathrm{T} 1$ and the deeper horizons of the (P3) profile, probably due to the poor drainage and the less intense weathering process, increasing the stability of smectite with Al in its structure.

The correlation analysis between the $\mathrm{Al}$ values determined by different methods (Al_Na, Al_AX, and $\mathrm{Al} \_\mathrm{Pl}$ ) and the $\mathrm{pH}$ in $\mathrm{H}_{2} \mathrm{O}$ and $\mathrm{KCl}$, and for $\mathrm{Ca}^{2+}$, clay CEC, ki and kr (Table 6), showed a significant and negative correlation, with higher $\mathrm{pH}$ values in $\mathrm{H}_{2} \mathrm{O}$ and clay CEC. The correlations between the different $\mathrm{Al}$ and clay methods were positive and significant. The results indicate that the higher the content of clay and the lower the values for clay CEC, ki and kr, the higher the $\mathrm{Al}$ content. That is, the greater the weathering degree of the soil, the greater the $\mathrm{Al}$ content. In studies of soils in the same region of Acre, Volkoff et al. (1989) stated that the distribution of exchangeable $\mathrm{Al}$ content follows the variation in the clay content, suggesting that a possible explanation for the high $\mathrm{Al}$ content is the destabilisation and destruction of clay, with subsequent $\mathrm{Al}$ release.

In a study of the mineralogy of three soils from a toposequence in Western Amazonia, Lima et al. (2006) observed the occurrence of smectite in an Ultisol with high CEC and Al contents, especially in the (deeper) 2C2 horizon, where the high content of bases and silica are sufficient for this mineral to be synthesised and stabilised, unlike in the surface horizons, where the activity of bioclimatic agents is more intense and the acidity is higher. Smectite becomes unstable under these conditions, degrading and releasing $\mathrm{Al}$ to the 
Table 5. Aluminium contents of the horizons determined by different methods

\begin{tabular}{|c|c|c|c|c|c|c|}
\hline Toposequence/profile/horizon & Alsol $^{(1)}$ & $\mathrm{Al} \_\mathrm{Na}$ & Al_AX & Al_Pl & Al_VPM & Al_VPT \\
\hline & \multicolumn{6}{|c|}{$-\mathrm{cmol}_{\mathrm{c}} \mathrm{kg}^{-1}-$} \\
\hline $\mathrm{T} 1 \mathrm{P} 1 \mathrm{Cv}_{3}$ & 0.02 & 1.5 & 1.7 & 2.5 & 0.7 & 0.8 \\
\hline $\mathrm{T} 1 \mathrm{P} 12 \mathrm{Cv}$ & - & 0.0 & 0.2 & 0.0 & 0.1 & 0.2 \\
\hline $\mathrm{T} 1 \mathrm{P} 22 \mathrm{Bi}_{2}$ & 0.02 & 11.8 & 13.1 & 11.4 & 6.7 & 7.5 \\
\hline T1P2 2C & 0.06 & 13.5 & 14.6 & 12.2 & 7.7 & 8.2 \\
\hline T1P3 Bi ${ }_{1}$ & 0.01 & 8.4 & 9.6 & 7.8 & 6.6 & 6.3 \\
\hline T1P3 2C ${ }_{2}$ & 0.03 & 0.6 & 0.5 & 0.4 & 0.3 & 0.5 \\
\hline $\mathrm{T} 2 \mathrm{P} 1 \mathrm{Bt}$ & 0.02 & 14.0 & 17.3 & 12.1 & 8.0 & 7.1 \\
\hline $\mathrm{T} 2 \mathrm{P} 1 \mathrm{Btf}_{3}$ & 0.02 & 13.6 & 16.8 & 12.5 & 5.1 & 7.1 \\
\hline $\mathrm{T} 2 \mathrm{P} 2 \mathrm{Bi}_{1}$ & - & 12.1 & 14.7 & 11.7 & 7.9 & 8.0 \\
\hline $\mathrm{T} 2 \mathrm{P} 2 \mathrm{C}_{2}$ & 0.23 & 1.3 & 1.6 & 1.2 & 0.7 & 0.8 \\
\hline T2P3 2Bg & 0.11 & 0.6 & 0.3 & 0.2 & 0.3 & 0.4 \\
\hline $\mathrm{T} 2 \mathrm{P} 32 \mathrm{Cg}_{1}$ & 0.29 & 0.0 & 0.2 & 0.1 & 0.2 & 0.2 \\
\hline T3P1 2Bt & 0.05 & 10.8 & 14.1 & 11.5 & 7.0 & 8.2 \\
\hline T3P2 Btf $_{1}$ & 0.02 & 13.2 & 17.8 & 14.2 & 5.3 & 8.0 \\
\hline T3P3 Bi & 0.04 & 9.6 & 12.4 & 9.9 & 5.8 & 8.1 \\
\hline T3P3 $\mathrm{Cv}_{2}$ & 0.07 & 1.0 & 1.0 & 0.6 & 7.7 & 7.7 \\
\hline Mean & 0.06 & 7.0 & 8.5 & 6.8 & 4.4 & 4.9 \\
\hline
\end{tabular}

(1) $\mathrm{Al}_{\mathrm{sol}}$ : water-soluble aluminium; $\mathrm{Al} \_\mathrm{Na}$ : aluminium determined by titration with $\mathrm{NaOH}$; $\mathrm{Al} \_\mathrm{AX}$ : aluminium determined by xylenol orange spectrometry; Al_PL: aluminium determined by plasma emission (ICP-OES); Al_VPM: monomeric aluminium determined by pyrocatechol violet spectrometry; Al_VPT: total aluminium determined by pyrocatechol violet spectrometry.

Table 6. Pearson correlation between $\mathrm{Al}$ content and properties of the horizons

\begin{tabular}{lccc}
\hline Property & Al_Na & Al_AX & Al_Pl \\
\hline $\mathrm{pH} \mathrm{H}{ }_{2} \mathrm{O}$ & $-0.84^{*}$ & $-0.81^{*}$ & $-0.82^{*}$ \\
$\mathrm{pH} \mathrm{KCl}$ & $-0.58^{*}$ & $-0.57^{*}$ & $-0.58^{*}$ \\
$\mathrm{Ca}^{2+}$ & $-0,91^{\mathrm{ns}}$ & $-0,89^{\mathrm{ns}}$ & $-0,90^{\mathrm{ns}}$ \\
$\mathrm{Clay}$ & $0.59^{*}$ & $0.60^{*}$ & $0.61^{*}$ \\
Clay CEC & $-0.68^{*}$ & $-0.69^{*}$ & $-0.70^{*}$ \\
$\mathrm{ki}$ & $-0.60^{*}$ & $-0.59^{*}$ & $-0.60^{*}$ \\
$\mathrm{kr}$ & $-0.58^{*}$ & $-0.58^{*}$ & $-0.57^{*}$ \\
\hline
\end{tabular}

* significant at $1 \%$; ns: not significant.

medium, which can lead to high exchangeable $\mathrm{Al}$ contents.

According to Coscione et al. (1998), the titration method is the least sensitive for exchangeable $\mathrm{Al}^{3+}$ determination. Bertsch \& Bloom (1996) stated that spectrophotometric methods for $\mathrm{Al}$ determination, e.g., ICP-OES, are doubtlessly the most sensitive and reliable. From the analysis of correlation of Al_PL with Al_Na and Al_AX, high correspondence was observed between the methods $(\mathrm{r}=0.99$, at $5 \%$ significance) (Figure 3), demonstrating that these methods are mutually comparable. However in general, the difference between the Al_Na and Al_PL values is less than the difference between the Al_Na and Al_AX values. This result may be due to the greater dilution of the extract required for determination by xylenol orange spectrometry, increasing the possibility of analytical error. The observed pattern does not disqualify this method for $\mathrm{Al}$ determination.

According to Pérez et al. (2009), the procedure of extraction with $\mathrm{KCl}$ and titration with $\mathrm{NaOH}$ determines $\mathrm{H}^{+}$, identified as exchangeable acidity (Sposito, 1989). Therefore, in this context, there is no differentiation between "exchangeable $\mathrm{H}^{+}$" and the $\mathrm{H}^{+}$ produced by the hydrolysis of $\mathrm{Al}$. This finding indicates that practically all of the $\mathrm{H}^{+}$determined by titration with $\mathrm{NaOH}$ originated from the hydrolysis of $\mathrm{Al}$, without much interference from other sources of $\mathrm{H}^{+}$, such as the $\mathrm{pH}$-dependent charges, due to the predominance of 2:1 clay minerals and the low organic matter content. The results demonstrate that the exchangeable acidity was mainly due to $\mathrm{Al}$, even at $\mathrm{pH}$ lower than 4.5.

When determining $\mathrm{Al}$ contents in 18 horizons of mineral soils with kaolinite and/or iron/aluminium oxyhydroxides as the main clay fraction minerals, Pérez et al. (2009) concluded that most protons quantified in the extracts of the mineral soils, i.e., the exchangeable acidity, originated from the hydrolysis of exchangeable Al.

Despite the similar results, the different methods for determining $\mathrm{Al}$ were not capable of quantifying exclusively exchangeable $\mathrm{Al}$, which is toxic to plants, due to the ability of $\mathrm{KCl}$ to extract non-exchangeable $\mathrm{Al}$ forms (Abreu Jr. et al., 2003). According to Ross et al. (2008), the repeated extraction with a neutral salt 
continuously removes $\mathrm{Al}$ in quantities according to the $\mathrm{pH}$ of the soil and solution combination. According to Wadt (2002) and Marques et al. (2002), this distortion in the exchangeable $\mathrm{Al}$ content, as an indicator of soil acidity, is exacerbated because $\mathrm{KCl}$ as extractant causes the dissolution of the low crystallinity forms of $\mathrm{Al}$ and of the interlayered $\mathrm{Al}$, which are non-exchangeable forms and, therefore, have a very tenuous equilibrium with the soil solution. Accordingly, the presence of 2:1 clay minerals with interlayered hydroxyl-Al leads to an overestimation of exchangeable $\mathrm{Al}$, i.e., the extract consists mainly of non-phytotoxic non-exchangeable $\mathrm{Al}$.

To explain the effect of the non-phytoxicity of $\mathrm{Al}$, Wadt (2002) stated that in the case of the soils of Acre, the adsorbent surface has high electronegativity and attracts cations with smaller hydrated ionic radius and greater valence more effectively. The cations adsorbed in this way are less active in the soil solution. On the other hand, other cations with larger hydrated ion radius and lower valence are released to the soil solution, where they have greater activity. In practice, these mechanisms reduce the quantity of Al that can reach the plant root systems and, therefore, its phytotoxic effect.

According to Araújo (2008), for the conditions of some of the soils of Acre, which have high $\mathrm{Ca}, \mathrm{Mg}$ and exchangeable $\mathrm{Al}$ contents, root development is not harmed because of the high Ca activity in solution, which can reduce the problems arising from acidity.

The smectite surface (2:1 clay minerals) has a permanent negative charge, which allows hydroxyl$\mathrm{Al}$, positively-charged polymers, to be adsorbed (Kämpf \& Curi, 2003). Due to its low stability, subject to release by weathering, the hydroxyl-Al can be indicated as the cause of the high $\mathrm{Al}$ contents. Therefore, smectites may play an important role in the adsorption of $\mathrm{Al}$, reducing its activity in the soil solution.

In the acidic mineral soils, the titrated $\mathrm{H}^{+}$in the non-buffered $\mathrm{KCl}$ solution does not represent the exchangeable acidity of the soil, but the low stability of the hydroxyl-Al forms, except in soils with high organic matter contents (Raij et al., 2001).

\section{CONCLUSIONS}

1. The $\mathrm{Al}$ contents determined by titration with $\mathrm{NaOH}$, xylenol orange spectrometry and ICP-OES were similar. However, the pyrocatechol violet method did not obtain consistent data. Extraction with $\mathrm{KCl}$ overestimated the exchangeable $\mathrm{Al}$ content due to its ability to extract the non-exchangeable $\mathrm{Al}$ present in the smectite interlayers.

2. It was observed that a high $\mathrm{Al}$ content is related to the instability of the hydroxyl-Al smectite interlayers. The horizons with the lowest degree of weathering, demonstrated by relatively low values for clay CEC, ki and kr, and by the mineralogy with most intense smectite reflections, have lower $\mathrm{Al}$ contents.

\section{LITERATURE CITED}

ABREU JR., C.H.; MURAOKA, T. \& LAVORANTE, A.F. Exchangeable aluminum evaluation in acid soils. Sci. Agric., 60:543-548, 2003.

ACRE. Governo do Estado do Acre. Programa Estadual de Zoneamento Ecológico Econômico do Estado do Acre. Zoneamento ecológico - econômico: recursos naturais e meio-ambiente. Documento final. Rio Branco, SECTMA, 2000. v.1. 178 p.

AMARAL, E.F. Ambientes, com ênfase nos solos e indicadores ao uso agroflorestal das bacias dos rios Acre e Iaco, Acre, Brasil. Viçosa, Universidade Federal de Viçosa, 2003. 129p. (Dissertação de Mestrado)

ARAÚJO, E.A.; LANI, J.L.; AMARAL, E.F. \& GUERRA, A. Uso da terra e propriedades físicas e químicas de Argissolo Amarelo distrófico na Amazônia Ocidental. R. Bras. Ci. Solo, 28:307-315, 2004.

ARAÚJO, E.A. Qualidade do solo em sistema de mata nativa e pastagens na região leste do Acre, Amazônia Ocidental. Viçosa, Universidade Federal de Viçosa, 2008. 233p. (Tese de Doutorado)

BARNHISEL, R.I. \& BERTSCH, P.M. Chlorites and hydroxyinterlayered vermiculite and smectite. In: DIXON, J.B. \& WEED, S.B., eds. Minerals in soil environments. 2.ed. Madison, Soil Science Society of America, 1989. p.729-788.

BERTSCH, P.M. \& BLOOM, P.R. Aluminum. In: SPARKS, D.L., ed. Methods of soil analysis. Madison, Soil Science Society of America, 1996. p.517-550. (Book Series, 5)

BOEIRA, R.C.; MAXIMILIANO, V.C.B. \& RAIJ, B.van. Comparação de dois métodos de determinação de alumínio trocável em solos tropicais. 2004. Available: <http:// www.infoteca.cnptia.embrapa.br/bitstream/item/12270/3/ artcongresA57.pdf $>$.

BRANCO, P.M. Dicionário de Mineralogia. 3.ed. Porto Alegre, Sagra, 1987. 362p.

BRASIL. Ministério das Minas e Energias. Departamento Nacional da Produção Mineral. Projeto RADAMBRASIL Levantamento de recursos naturais. Folhas SC. 19 Rio Branco: Geologia, geomorfologia, pedologia, vegetação, uso potencial da terra. Rio de Janeiro, Divisão de Publicação, 1976. 464p. 12v.

BRAUNER, J.L. Extração e determinação do alumínio trocável do solo; variação no seu teor influenciado pela aplicação de carbonato de cálcio. Piracicaba, Escola Superior de Agricultura "Luiz de Queiroz", 1966. 34p. (Dissertação de Mestrado)

BRINDLEY, G.W. \& BROWN, G. Crystal structures of clay minerals and their X-ray identification. London, Mineralogical Society, 1984. 495p. 
CALDERANO, S.B.; DUARTE, M.N. \& GREGORIS, G. Análise mineralógica das frações finas do solo por difratometria de raios-X: Revisão e atualização da metodologia e critérios usados na Embrapa Solos. Rio de Janeiro, Embrapa Solos, 2009. (Embrapa Solos, Comunicado Técnico, 53)

CARTER, D.L.; HEILMAN, M.D. \& GONZALES, C.L. Ethylene glycol monoethyl ether for determining surface area of silicate minerals. Soil Sci., 100:356-360. 1965.

CAVALCANTE, L.M. Aspectos geológicos do Estado do Acre e implicações na evolução da paisagem. Rio Branco, Embrapa Acre, 2006a. 25p. (Documentos, 104)

CAVALCANTE, L.M. Relatório sobre a Geologia do Estado do Acre. Rio Branco, SEMA/IMAC, 2006b. (Texto Integrante do Eixo Recursos Naturais do ZEE Fase II)

CIHACEK, L.J. \& BREMNER, J.M. A simplified ethylene glycol monoethyl ether procedure for assessment of soil surface area. Soil Sci. Soc. Am. J., 43:821-822, 1979.

COSCIONE, A.R.; ANDRADE, J.C. \& RAIJ, B.van. Revisiting titration procedures for the determination of exchangeable acidity and exchangeable aluminum in soils. Commun. Soil Sci. Plant Anal., 29:973-982, 1998.

COSCIONE, A.R.; ANDRADE, J.C.; RAIJ, B.van \& ABREU, M.F. An improved analytical protocol for the routine spectrophotometric determination of exchangeable aluminum in soil extracts. Commun. Soil Sci. Plant Anal., $31: 2027-2037,2000$

DOUGAN, W.K. \& WILSON, A.L. The absorptiometric determination of aluminium in water. A comparison of some chromogenic reagents and the development of an improved method. Analyst, 99:413-430, 1974.

EBELING, A.G. Caracterização analítica da acidez em Organossolos. Seropédica, Universidade Federal Rural do Rio de Janeiro, 2006. 88p. (Dissertação de Mestrado)

EMPRESA DE PESQUISA AGROPECUÁRIA BRASILEIRA EMBRAPA. Centro Nacional de Pesquisa de Solos. Manual de métodos de análises de solo. Rio de Janeiro, 1997. $212 p$.

EMPRESA DE PESQUISA AGROPECUÁRIA BRASILEIRA EMBRAPA. Sistema brasileiro de classificação de Solos. 2.ed. Brasília, Embrapa Produção de informação; Rio de Janeiro, Embrapa Solos, 2006. 312p.

GAMA, J.R.N.F. Caracterização e formação de solos com argila de atividade alta do Estado do Acre. Itaguai, Universidade Federal Rural do Rio de Janeiro, 1986. 150p. (Dissertação de Mestrado)

GAMA, J.R.N.F. \& KIEHL, J.C. Influência do alumínio de um Podzólico Vermelho-Amarelo do Acre sobre o crescimento das plantas. R. Bras. Ci. Solo, 23:475-482, 1999.

HEILMAN, M.D.; CARTER, D.L \& GONZALEZ, C.L. The ethylene glycol monethyl ether (EGME) technique for determining soil surface area. Soil Sci., 100:409-413, 1965.

HIRADATE, S.; TANIGUCHI, S. \& SAKURAI, K. Aluminum speciation in aluminum-silica solutions and potassium chloride extracts of acidic soils. Soil Sci. Soc. Am. J., 62:630636, 1998.
KÄMPF, N. \& CURI, N. Argilominerais em solos brasileiros. In: CURI, N.; MARQUES, J.J.; GUILHERME, L.R.G.; LIMA, J.M.; LOPES, A.S. \& ALVAREZ V., V.H., eds. Tópicos em ciência do solo. Viçosa, MG, Sociedade Brasileira de Ciência do Solo, 2003. v.3. p.1-54.

KAMPRATH, E.J. Exchangeable aluminum as a criterion for liming leached mineral soil. Soil Sci. Soc. Am. Proc., 34:252, 1970.

KISSEL, D.E.; GENTZSCH, E.P. \& THOMAS, G.W. Hydrolysis of nonexchangeable acidity in soils during salt extractions of exchangeable acidity. Soil Sci., 111:293-297, 1971.

LIMA, H.N.; MELLO, J.W.V.; SCHAEFER, C.E.G.R.; KER, J.C. \& LIMA, A.M.N. Mineralogia e química de três solos de uma topossequência da bacia sedimentar do Alto Solimões, Amazônia ocidental. R. Bras. Ci. Solo, 30:5968, 2006.

MARQUES, J.J.; TEIXEIRA, W.G.; SCHULZE, D.G. \& CURI, N. Mineralogy of soils with unusually high exchangeable Al from the western Amazon Region. Clay Miner., 37:651661,2002

MAYLE, F.E. \& POWER, M.J. Impact of a drier Early-MidHolocene climate upon Amazonian forests. Phil. Trans. R. Soc. B., 363:1829-1838, 2008.

MEHRA, O.P. \& JACKSON, M.L. Iron oxide removal from soils and clays by a dithionite-citrate system buffered with sodium bicarbonate. In: CLAYS \& CLAY MINERAL CONFERENCE, 7., London, 1960. Proceedings... London, 1960. v.7. p.317-327.

MELO, V.F.; MATTOS, J.M.S.M. \& LIMA, V.C. Métodos de concentração de minerais $2: 1$ secundários na fração argila visando sua identificação por difratometria de raios-X. $\mathrm{R}$. Bras. Ci. Solo, 33:527-539, 2009.

MÖLLER, M.R.F. \& KITAGAMA, Y. Mineralogia de argilas em Cambissolos do sudoeste da Amazônia Brasileira. Belém, Embrapa CPATU, 1982. 19p. (Boletim de Pesquisa, 34)

MÖLLER, M.R.F.; KITAGAMA, Y. \& COSTA, M.P. Distribuição aproximada de minerais argilosos na folha SC-19 Rio Branco. In: ENCONTRO DE PROFISSIONAIS DE QUÍMICA DA AMAZÔNIA, 3., 1982. Manaus, Anais.... Manaus, 1982. p.291-306.

MOORE, D.M. \& REINOLDS JR., R.C. X-ray diffraction and the identification and analysis of clay minerals. 2.ed. Oxford, Oxford University Press, 1997. 378p

OATES, K.M. \& KAMPRATH, E.J. Soil acidity and liming: I. Effect of the extracting solution cation and $\mathrm{pH}$ on the removal of aluminum from acid soils. Soil Sci. Soc. Am. J., 47:686-689, 1983.

PAVAN, M.A. Alumínio em solos ácidos do Paraná: Relação entre o alumínio não-trocável, trocável e solúvel, com o pH, CTC, porcentagem de saturação de Al e matéria orgânica. R. Bras. Ci. Solo, 7:39-46, 1983.

PÉREZ, D.V.; ANJOS, L.H.C.; EBELING, A.G. \& PEREIRA, M.G. Comparison of $\mathrm{H} / \mathrm{Al}$ stoichiometry of mineral and organic soils in Brazil. R. Bras. Ci. Solo. 33:1071-1076, 2009 . 
RAIJ, B.van; ANDRADE, J.C.; CANTARELLA, H. \& QUAGGIO, J.A. Análise química para avaliação da fertilidade de solos tropicais. Campinas, Instituto Agronômico de Campinas, 2001. 285p.

RAIJ, B.van; QUAGGIO, J.A.; CANTARELLA, H.; FERREIRA, M.E. \& LOPES, A.S. \& BATAGLIA, O.C. Análise química do solo para fins de fertilidade. Campinas, Fundação Cargill, 1987. 170p.

ROSSETTI, D.F. \& TOLEDO, P.M. Environmental changes in Amazonia as evidenced by geological and paleontological data. R. Bras. Ornitol., 15:175-188, 2007.

ROSS, D.S.; MATSCHONAT, G. \& SKYLLBERG, U. Cation exchange in forest soils: the need for a new perspective. Eur. J. Soil Sci, 59:1141-1159, 2008.

SANTOS, R.D.; LEMOS, R.C.; SANTOS, H.G.; KER, J.C. \& ANJOS, L.H.C. Manual de descrição e coleta de solo no campo. 5.ed. Viçosa, MG, Sociedade Brasileira de Ciência do Solo; Embrapa Solos, 2005. 100p.
SILVA, J.R.T. Solos do Acre: Caracterização física, química e mineralógica e adsorção de fosfato. Viçosa, Universidade Federal de Viçosa, 1999. 117p. (Tese de Doutorado)

SOIL SURVEY STAFF. Soil taxonomy: A basic system of soil classification for making and interpreting soil surveys. 2.ed. Washington, DC, USDA-Natural Resources Conservation Service, 1999. 871p.

SPOSITO, G. The chemistry of soils. New York, Oxford University Press, 1989. p.209-225.

THOREZ, J. Practical identification of clay minerals. Liege, Liege State University, 1976. 90p.

VOLKOFF, B.; MELFI, A.J. \& CERRI, C.C. Solos Podzólicos e Cambissólicos eutróficos do Alto Purus (Estado do Acre). R. Bras. Ci. Solo, 13:363-372, 1989.

WADT, P.G.S. Manejo de solos ácidos do Estado do Acre. Rio Branco, Embrapa Acre, 2002. 28p. (Embrapa Acre. Documentos, 79) 